\title{
Sleep Mode Strategy for Energy Saving on 3G Network
}

\author{
Linawati $^{1 *}$, Gede Sukadarmika ${ }^{2}$ and Ridho Yurham $^{3}$ \\ ${ }^{1 * 2,3}$ Department of Electrical and Computer Engineering, Udayana University \\ Bali, Indonesia \\ linawati@unud.ac.id
}

\begin{abstract}
Cellular telecommunication services are basic needs both in developed and developing countries. Recently, most multimedia and video traffic are transmitted on cellular telecommunication infrastructure. These traffic cause providers to increase their infrastructure capacity. The increased capacity on the other hand will increase their energy usage. However the infrastructure is not used at its fully capacity for twenty four hours. Therefore this paper will investigate traffic profile of $3 G$ system of one telecommunication provider in a District of West Denpasar City for two months in order to analyze its energy usage. The research analyzes energy consumption of 29 of $3 G$ base stations. Then traffic profile of workday and weekend were captured. The lowest traffic was found from 03:0:0 AM to 05:0:0 AM everyday on workday and weekend. Thus sleep mode method was proposed to apply for all $3 G$ base stations during these hours. The results showed that the sleep mode implementation could reduce its energy consumption significantly up to 3,374 $\mathrm{kW}$ a year. In addition there was improvement on Area Power Consumption (APC) ratio about $146.487 \mathrm{~W} / \mathrm{km} 2$ and $111.98 \mathrm{~W} / \mathrm{km} 2$ on both months respectively. On the other side, during the sleep mode implementation, the coverage of $3 G$ services reduces up to $3.10 \%$. However, the reduction on $3 G$ coverage could be substituted by $2 G$ services. As a result the provider could maintain its services quality.
\end{abstract}

Keywords: Energy Usage, Traffic Profile, Sleep Mode

\section{Introduction}

The need on telecommunication services especially cellular telecommunication rapidly increases every year. Cellular traffic was estimated up to 6.3 Exabyte per month in 2015 [1]. This demand causes significant increases of base stations development, especially in developing countries, such as in Indonesia [2]. The similar situation has occurred in Denpasar City as capital of Bali Island which is one of five big cities in Indonesia. Area of Denpasar city is $127.78 \mathrm{~km}^{2}$ and it is divided to be four Districts. The population was 880,600 (year 2015) [3]. Although the city area is small, all cellular providers, i.e. totally five providers in Indonesia are running their business in Denpasar [4]. All providers continuously increase their networks capacity to satisfy their users need. This increase has an impact on energy usage for telecommunication services. Therefore there are many researches on green cellular technology [5-9].

Sleep mode is one of strategies for green telecommunication [5]. This method used traffic prediction to choose suitable BS (Base Station) to be turn into sleep state. The research used sleep mode and maximum power transmission of base station side to reduce energy consumption. Other research proposed Self-Organizing Pilot-Power Adjustment Mechanism (SPAM) algorithm [6]. The result shows that this algorithm could reduce energy consumption up to $17 \%$ in homogenous cell deployment simulations.

This paper proposes the implementation of the sleep mode strategy on existing $3 \mathrm{G}$ network in Denpasar area. The research is initiated by modelling the traffic profile. Then 
green metric value is obtained. Finally a comparison between the energy consumption of existing network with and without sleep mode implementation is discussed.

\section{Green Cellular Network}

The implementation of Information Communication Technology (ICT) facilities are growing rapidly across the world. This condition will result an energy crisis. This also triggers greenhouse gases and global warming. Based on that, industrial, government and academic stakeholders have conducted research on green cellular network. The technology has to do the best tradeoff between energy consumption and network performance such as QoS, Throughput, and Scalability [5]. Therefore the technology could reduce the electricity bill that economically helps the cellular operators.

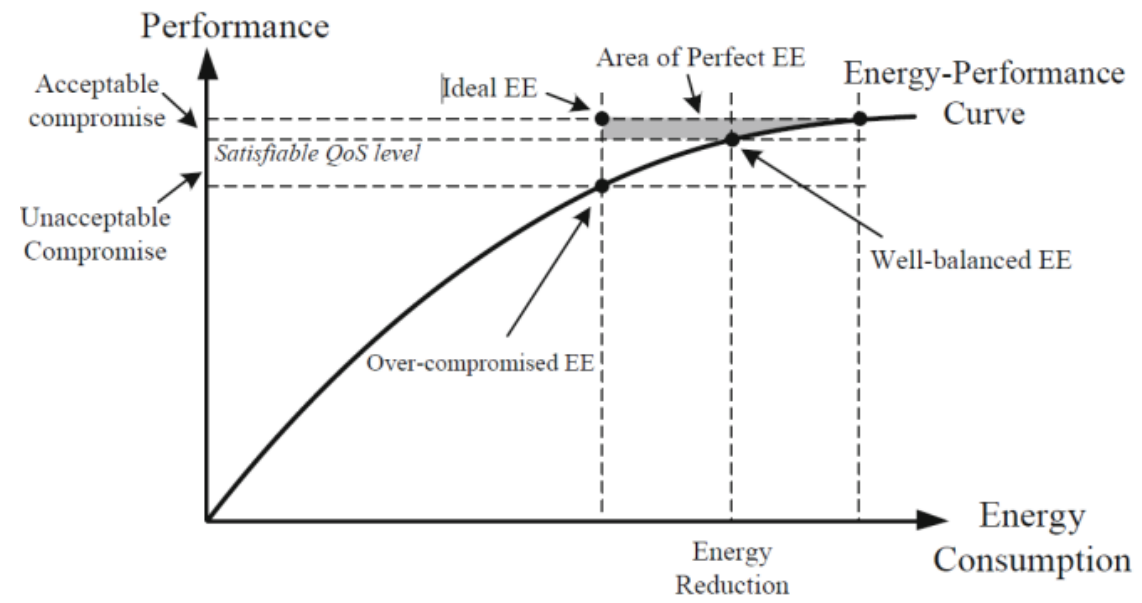

Figure 1. Energy- Performance Trade Off in Mobile Communication [5]

\subsection{Green Metrics}

There are two types of green metrics i.e. green metrics at equipment levels and at facility levels [8]. The equipment level metrics evaluate each peripheral in low level consumption. This metrics include Energy Consumption Rating (ECR), Consumer Consumption Rating (CCR) developed by IXIA and Juniper, Telecommunication Energy Efficiency Rating (TEER) proposed by ATIS and many more. The facility levels metrics evaluate higher level consumption in macro perspective. The metrics include Power Usage Effectiveness (PUE), Data Center infrastructure Efficiency (DCiE), and Data Center Productivity (DCP) proposed by Green Grid. Basically, ECR is the ratio of energy used per bit of data that mathematically shown as:

$$
E C R=\frac{P_{\max }}{C_{\max }}[\text { Watt } / \text { bps }]
$$

Moreover, Area Power Consumption (APC) is a metric that calculate power usage (P) per area (S). APC is expressed as:

$$
A P C=\frac{p}{s}\left[W a t t / \mathrm{km}^{2}\right]
$$

From ECR and APC, it is derived the new metric to evaluate the adaptive technique [5] shown below:

$$
Y=\frac{p}{c_{\mathrm{raq}} \mathrm{q}^{5}}\left[\text { Watt } \cdot \mathrm{bps}^{-1} \cdot \mathrm{km}^{-2}\right]
$$




\subsection{High Speed Downlink Packet Access}

High Speed Downlink Packet Access (HSDPA) is mobile communication technology designed to W-CDMA network with data transmission speed up to 5 times from the last generation. The UMTS is known as third generation (3G), then the HSDPA is known as 3,5G. In W-CDMA networks, we can divide the network into two big groups Access Network called Universal Terrestrial Radio Access Network (UTRAN) and Core Network [10] as seen in Figure 2.

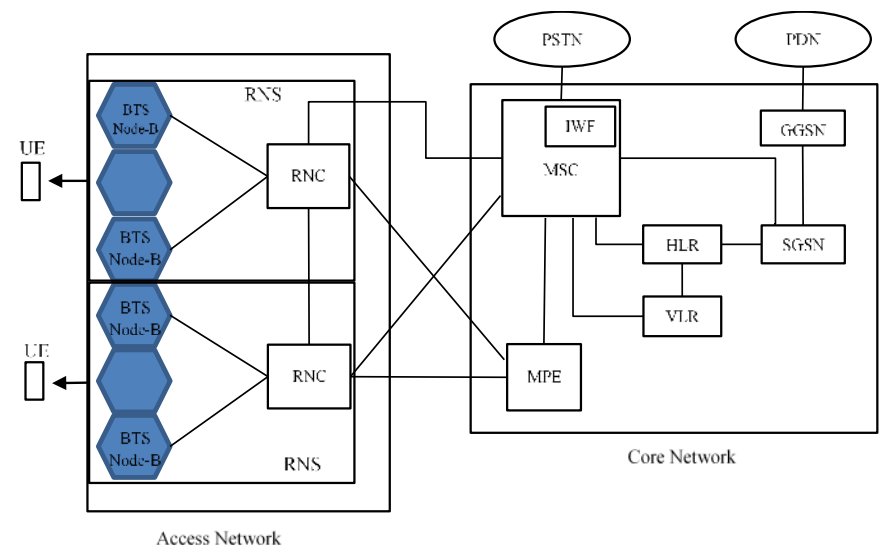

Figure 2. WCDMA/UMTS/HSDPA Architecture [10]

\subsection{Power Model}

Power Model is an interface model between component and system levels. The model could measure how energy reduction on certain component that can affect the energy efficiency in node and networks [9]. The Power model for variable traffic loads can be modeled by:

For $0 \leq P_{\text {out }} \leq P_{\max }$

$$
P_{\text {in }}=N_{T R X} \cdot\left(P_{0}+\Delta_{p} P_{\text {out }}\right)
$$

$\mathrm{P}_{\max }$ is the maximum value of RF output power on the maximum load. $\mathrm{P}_{0}$ is the minimum power output which can be assumed as $1 \%$ from $\mathrm{P}_{\max }$, and $\Delta \mathrm{p}$ is a slope from power consumption that depends on the load. Table 1 shows power model parameter that is adopted for this research.

Table 1. Power Model Parameter [9]

\begin{tabular}{|l|c|c|c|c|}
\hline \multicolumn{1}{|c|}{ Type BS } & $\mathbf{N}_{\text {TRx }}$ & $\mathbf{P}_{\max }(\mathbf{W})$ & $\mathbf{P}_{\mathbf{0}}(\mathbf{W})$ & $\Delta_{\mathbf{p}}$ \\
\hline Macro & 6 & 40 & 118.7 & 2.66 \\
\hline Micro & 2 & 6.3 & 53 & 3.1 \\
\hline Pico & 2 & 0.13 & 6.8 & 4 \\
\hline Femto & 2 & 0.05 & 4.8 & 7.5 \\
\hline
\end{tabular}

\section{Research Method}

In this research, following data are required to collect: specifications data of Base Station as a sample, data of the Base Stations coverage area, and data of the Base Stations traffic. Then we collected the energy consumption data of the existing Base Station system. Next step is to analyze the existing condition, including traffic profile, coverage area of each Base Station, and power consumption using Power Model calculation. Subsequently, we simulated and analyzed sleep mode strategy implementation on existing 
network, including traffic classification based on traffic profile and time range, base station power consumption, and its coverage area. Finally the Green Metrics using ECR, APC, and Y were evaluated.

The sleep mode range time depends on the traffic profile. We call this range time as Sleep Mode Hours, and the other as Normal Hours. Then, we select the BS sites that have low traffic profile. The traffic threshold is made based on the lower quartile each BS site at 01.00 AM until 06.00 AM. Then calculate power model for each site after sleep mode applied. Finally, we calculate the green metric as comparison between existing conditions and after sleep mode condition is applied. Lower green metric value describes the system more efficient and more energy conservation. However the sleep mode utilization causes reduction of base station coverage.

\section{Results and Discussions}

\subsection{Base Station Deployment in Denpasar Area}

The research was done in Denpasar City. The city has four Districts, i.e. West Denpasar, East Denpasar, North Denpasar, and South Denpasar. Data of all 3G Base Stations of one Telecommunication Provider in West Denpasar were selected to be sample. This area has been chosen as the area is the most densely populated in the city with the most number of Base Stations, as shown in Table 2. Thus the sites of West Denpasar could be a good representative of Denpasar City generally. West Denpasar has 29 sites of $3 \mathrm{G}$ which is controlled by 1 RNC (Radio Network Controller). Figure 3 displays the sites in West Denpasar.

Table 2. Site Deployment

\begin{tabular}{|c|l|c|c|c|}
\hline No. & \multicolumn{1}{|c|}{ District } & $\begin{array}{c}\text { Number of } \\
\text { 2G Site }\end{array}$ & $\begin{array}{c}\text { Number } \\
\text { of 3G Site }\end{array}$ & Total Site \\
\hline 1 & East Denpasar & 40 & 26 & $\mathbf{6 6}$ \\
\hline 2 & South Denpasar & 44 & 25 & $\mathbf{6 9}$ \\
\hline 3 & West Denpasar & 65 & 36 & $\mathbf{1 0 1}$ \\
\hline 4 & North Denpasar & 1 & 3 & $\mathbf{4}$ \\
\hline \multicolumn{4}{|c|}{ Total Site } & $\mathbf{2 4 0}$ \\
\hline
\end{tabular}




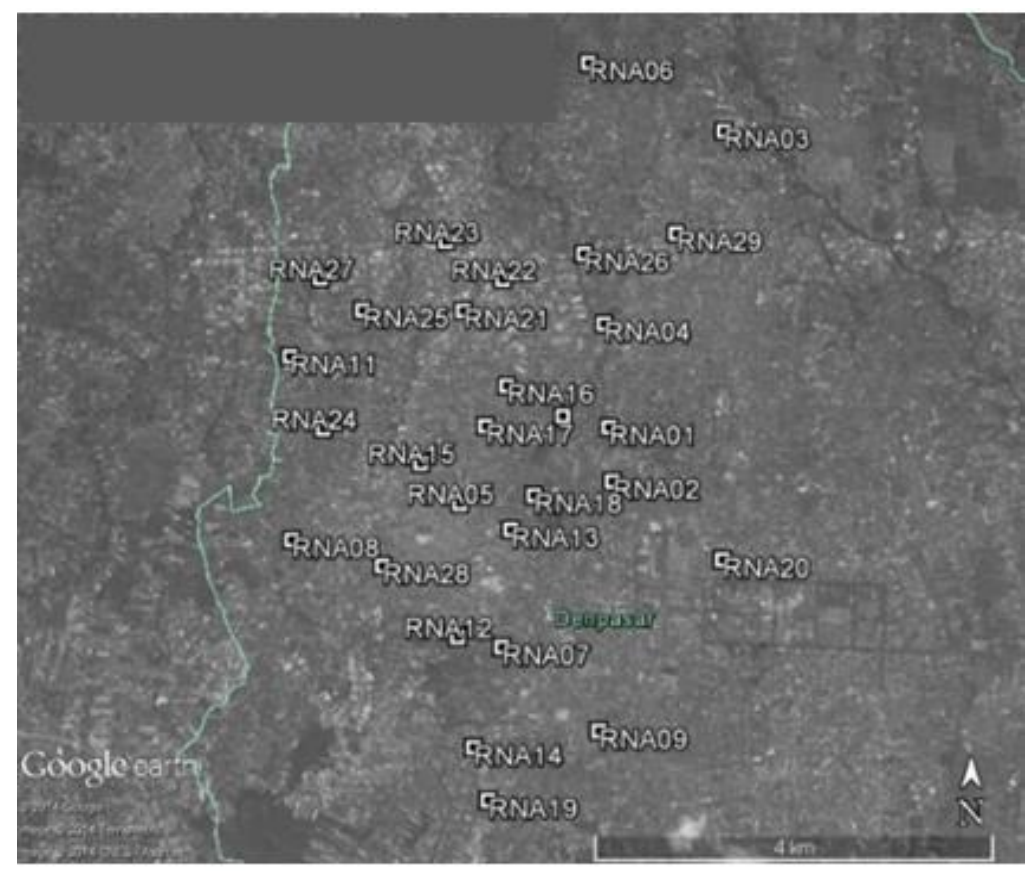

Figure 3. West Denpasar Base Station Deployment

\subsection{Traffic Profile Analysis}

The average traffic profiles from each sampled Base Station is classified into two (2) types i.e. work day and weekend traffic profile. The classification results are shown in Figure 4 and Figure 5. From those figures can be seen that lower traffic load happened between $01.00 \mathrm{AM}$ until 06.00 AM. Therefore, this research chooses the time range from 01.00 AM to 06.00 as the sleep mode time.

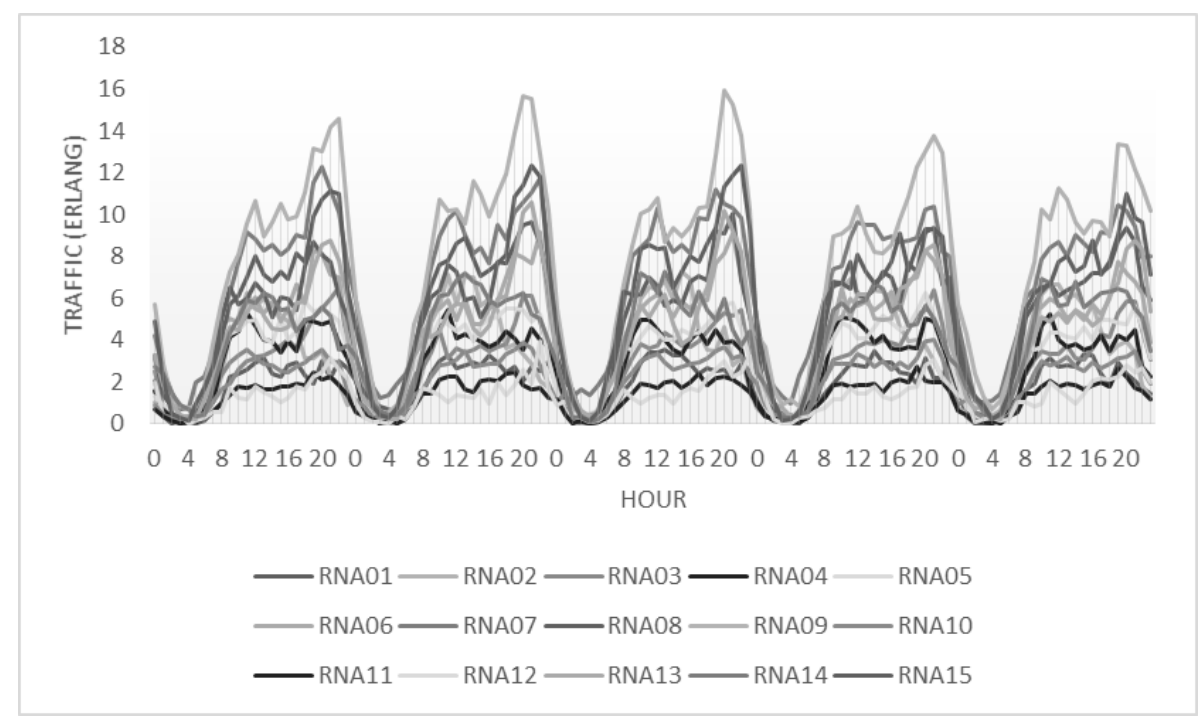

Figure 4. Workday Average Traffic Profile (RNA1-RNA15) (1 Month) 


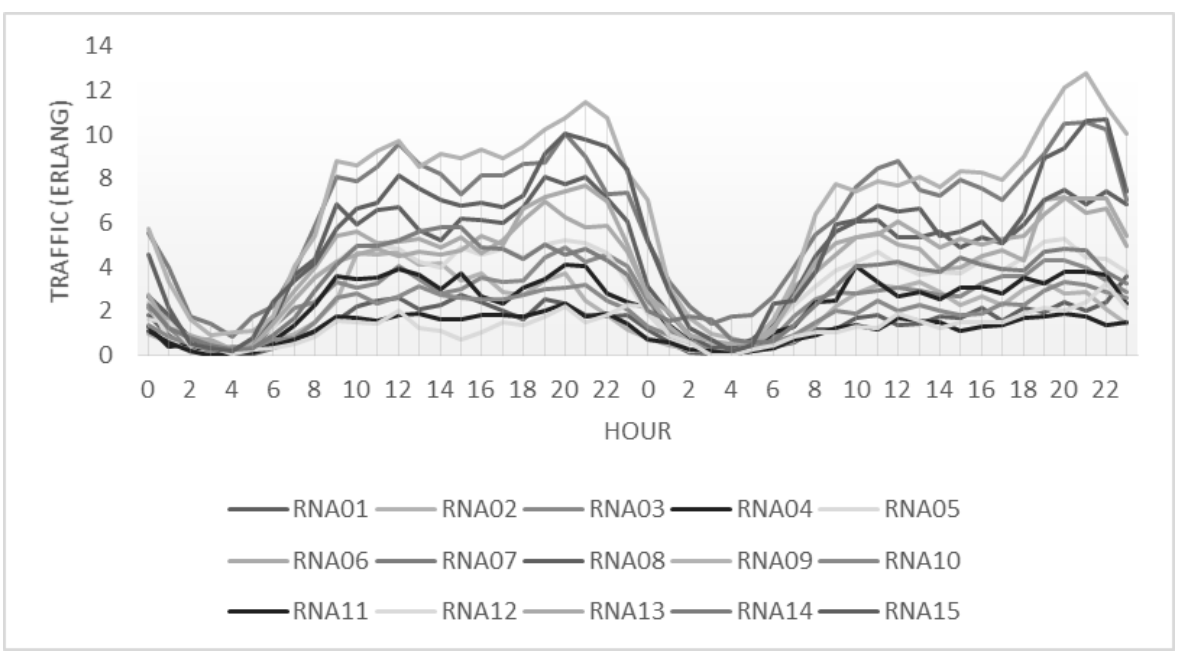

Figure 5. Weekend Average Traffic Profile (RNA1-RNA15) (1 Month)

We chose the site and the time range based on the threshold value. This value is the minimum lower quartile of average each hour traffic profile on workday and weekend from 01.00 AM until 06.00 AM. The results of this calculation are shown in Table 3. Then we conducted site tests to identify sleep mode time range using the threshold time. The event when traffic is lower than the threshold as shown in Table 4 and Table 5. Based on those tables, we found that sleep mode could be implemented between 03.00 AM until $05.00 \mathrm{AM}$.

Table 3. Traffic Threshold

\begin{tabular}{|c|c|c|}
\hline & $\begin{array}{c}\text { Workday } \\
\text { (Erlang) }\end{array}$ & $\begin{array}{c}\text { Weekend } \\
\text { (Erlang) }\end{array}$ \\
\hline March & 0.10825 & 0.1437 \\
\hline April & 0.166666667 & 0.14775 \\
\hline
\end{tabular}

Table 4. Workday Events below the Threshold

\begin{tabular}{|c|c|c|c|c|c|c|}
\hline \multirow{2}{*}{ Day } & \multicolumn{7}{|c|}{ Events Each Hour } \\
\cline { 2 - 7 } & $\mathbf{1 : 0 0}$ & $\mathbf{2 : 0 0}$ & $\mathbf{3 : 0 0}$ & $\mathbf{4 : 0 0}$ & $\mathbf{5 : 0 0}$ & $\mathbf{6 : 0 0}$ \\
AM & AM & AM & AM & AM & AM \\
\hline Monday & 0 & 3 & 4 & 6 & 2 & 0 \\
\hline Tuesday & 0 & 1 & 7 & 6 & 2 & 0 \\
\hline Wednesday & 0 & 0 & 2 & 5 & 8 & 4 \\
\hline Thursday & 0 & 1 & 2 & 5 & 1 & 0 \\
\hline Friday & 0 & 3 & 5 & 4 & 2 & 0 \\
\hline Events Total & $\mathbf{0}$ & $\mathbf{8}$ & $\mathbf{2 0}$ & $\mathbf{2 6}$ & $\mathbf{1 5}$ & $\mathbf{4}$ \\
\hline
\end{tabular}

Table 5. Weekend Events below the Threshold

\begin{tabular}{|c|c|c|c|c|c|c|}
\hline \multirow{3}{*}{ Day } & \multicolumn{7}{|c|}{ Events Each Hour } \\
\cline { 2 - 7 } & $\mathbf{1 : 0 0}$ & $\mathbf{2 : 0 0}$ & $\mathbf{3 : 0 0}$ & $\mathbf{4 : 0 0}$ & $\mathbf{5 : 0 0}$ & $\mathbf{6 : 0 0}$ \\
& $\mathbf{A M}$ & $\mathbf{A M}$ & $\mathbf{A M}$ & $\mathbf{A M}$ & $\mathbf{A M}$ & $\mathbf{A M}$ \\
\hline Saturday & 0 & 0 & 1 & 8 & 7 & 4 \\
\hline Sunday & 0 & 1 & 4 & 4 & 0 & 0 \\
\hline Event Total & $\mathbf{0}$ & $\mathbf{1}$ & $\mathbf{5}$ & $\mathbf{1 2}$ & $\mathbf{7}$ & $\mathbf{4}$ \\
\hline
\end{tabular}


After deciding the sleep mode hours, we focused on microcells which has events frequently below the threshold during sleep mode hours. Here, the RNA03, RNA06 and RNA09 were not included due to their location in separated area other site. The result of the site test on March showed that there were 4 sites which have ratio of sleep mode hours more than 50\% on sleep mode. The sites that can be seen in Table 6, are RNA01 (75\%), RNA11 (73\%), RNA12 (68\%), and RNA29 (58\%). Those 4 sites then were chosen to apply the sleep mode strategy.

From coverage radius calculation we found that there were two types of BSs. We classified them into two groups, i.e. macro cell for site coverage radius of $0.666 \mathrm{~km}$, and $0.572 \mathrm{~km}$ for microcell. This category was used for sleep mode application. Those the 29 Base Station site coverage and deployment is shown in Figure 6.

Table 6. The Microcell Site Sleep Mode Ratio (1 Month)

\begin{tabular}{|c|c|c|c|c|}
\hline No & Site Name & $\begin{array}{c}\text { Total Sleep } \\
\text { Mode Hour }\end{array}$ & $\begin{array}{c}\text { Activated Sleep } \\
\text { Mode Hour }\end{array}$ & $\begin{array}{c}\text { Ratio of Sleep } \\
\text { Mode }\end{array}$ \\
\hline $\mathbf{1}$ & RNA01 & 93 & 70 & $75 \%$ \\
\hline $\mathbf{2}$ & RNA03 & 93 & 49 & $53 \%$ \\
\hline $\mathbf{3}$ & RNA05 & 93 & 13 & $14 \%$ \\
\hline $\mathbf{4}$ & RNA06 & 93 & 17 & $18 \%$ \\
\hline $\mathbf{5}$ & RNA07 & 93 & 2 & $2 \%$ \\
\hline $\mathbf{6}$ & RNA08 & 93 & 19 & $20 \%$ \\
\hline $\mathbf{7}$ & RNA09 & 93 & 4 & $4 \%$ \\
\hline $\mathbf{8}$ & RNA11 & 93 & 68 & $73 \%$ \\
\hline $\mathbf{9}$ & RNA12 & 93 & 63 & $68 \%$ \\
\hline $\mathbf{1 0}$ & RNA14 & 93 & 8 & $9 \%$ \\
\hline $\mathbf{1 1}$ & RNA15 & 93 & 12 & $13 \%$ \\
\hline $\mathbf{1 2}$ & RNA16 & 93 & 16 & $17 \%$ \\
\hline $\mathbf{1 3}$ & RNA18 & 93 & 20 & $22 \%$ \\
\hline $\mathbf{1 4}$ & RNA22 & 93 & 18 & $19 \%$ \\
\hline $\mathbf{1 5}$ & RNA25 & 93 & 27 & $29 \%$ \\
\hline $\mathbf{1 6}$ & RNA27 & 93 & 17 & $18 \%$ \\
\hline $\mathbf{1 7}$ & RNA28 & 93 & 11 & $12 \%$ \\
\hline $\mathbf{1 8}$ & RNA29 & 93 & 54 & $58 \%$ \\
\hline
\end{tabular}




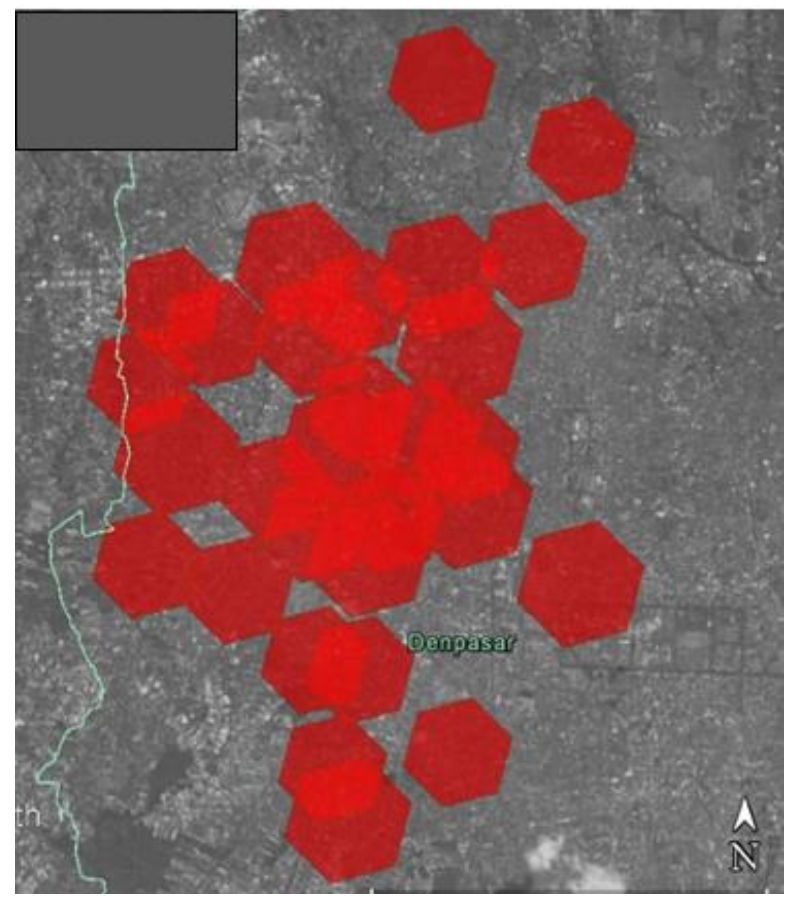

Figure 6. The $3 \mathrm{G}$ Coverage Areas in West Denpasar

The worst condition of sleep mode implementation is, when all of the chosen site are set to the sleep state. It would reduce the $3 \mathrm{G}$ coverage. The coverage reductions are shown in Figure 7 and Table 7 . However, the services to the area is then handled by $2 \mathrm{G}$ system. This means that the services on those area decreases from $3 \mathrm{G}$ to $2 \mathrm{G}$ system.

Table 7. Reduction Coverage of 3G System on Sleep Mode State

\begin{tabular}{|c|c|c|c|c|c|}
\hline NO & Site Condition & $\begin{array}{c}\text { 3G Coverage Area } \\
\left(\mathbf{k m}^{\mathbf{2}}\right)\end{array}$ & $\begin{array}{c}\mathbf{2 G} \text { Coverage Area } \\
\mathbf{( k m}^{\mathbf{2}} \mathbf{(}\end{array}$ & $\begin{array}{c}\text { Blank } \\
\text { Spot } \\
\left(\mathbf{k m}^{\mathbf{2}} \mathbf{)}\right.\end{array}$ & $\begin{array}{c}\text { Reduction } \\
\mathbf{( \% )}\end{array}$ \\
\hline $\mathbf{1}$ & All Live & 21.47 & 0 & 0 & $0.00 \%$ \\
\hline $\mathbf{2}$ & 01 & 21.44 & 0.14 & 0.03 & $0.14 \%$ \\
\hline $\mathbf{3}$ & 11 & 21.304 & 0.582 & 0.166 & $0.77 \%$ \\
\hline $\mathbf{4}$ & 12 & 21.35 & 0.35 & 0.12 & $0.56 \%$ \\
\hline $\mathbf{5}$ & 29 & 21.12 & 0.402 & 0.35 & $1.63 \%$ \\
\hline $\mathbf{6}$ & $01-11$ & 21.274 & 0.772 & 0.20 & $0.91 \%$ \\
\hline $\mathbf{7}$ & $01-12$ & 21.32 & 0.49 & 0.47 & $0.70 \%$ \\
\hline $\mathbf{8}$ & $01-29$ & 21.09 & 0.542 & 0.38 & $1.77 \%$ \\
\hline $\mathbf{9}$ & $11-12$ & 21.184 & 0.932 & 0.29 & $1.33 \%$ \\
\hline $\mathbf{1 0}$ & $11-29$ & 20.954 & 0.984 & 0.52 & $2.40 \%$ \\
\hline $\mathbf{1 1}$ & $12-29$ & 21.24 & 0.752 & 0.47 & $1.07 \%$ \\
\hline $\mathbf{1 2}$ & $01-11-12$ & 21.154 & 1.122 & 0.32 & $1.47 \%$ \\
\hline $\mathbf{1 3}$ & $01-11-29$ & 20.924 & 1.174 & 0.55 & $2.54 \%$ \\
\hline $\mathbf{1 4}$ & $01-12-29$ & 20.97 & 0.892 & 0.50 & $2.33 \%$ \\
\hline $\mathbf{1 5}$ & $11-12-29$ & 20.834 & 1.334 & 0.64 & $2.96 \%$ \\
\hline $\mathbf{1 6}$ & All sleep & 20.804 & 1.474 & 0.67 & $3.10 \%$ \\
\hline
\end{tabular}




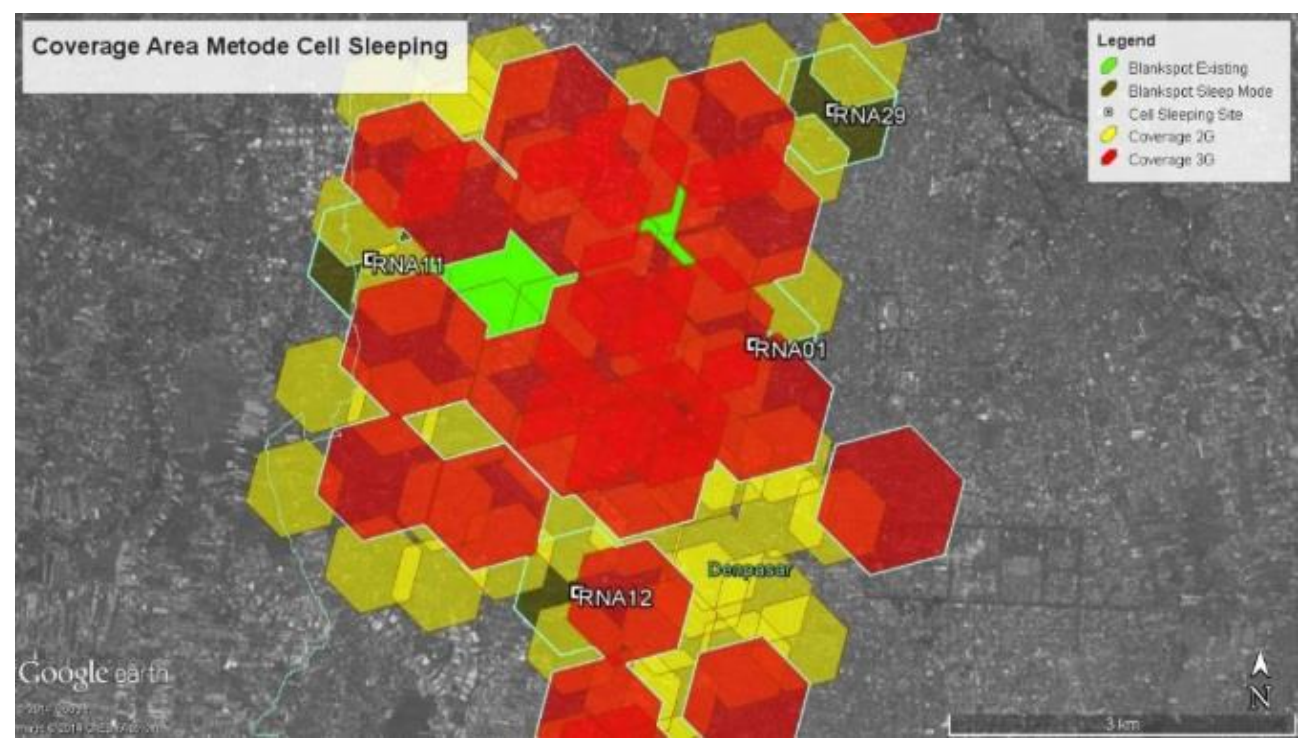

Figure 7. Coverage Area on the Worst Conditions of Sleep Mode Implementation

\subsection{Energy Consumption when Sleep Mode Implemented}

When sleep mode strategy is activated, then energy consumption of the site is determined by transmission power. During the sleep hours, when traffic load of the chosen sites are lower than the threshold, then the sites are set inactive or in sleep condition. This means that the sleep mode strategy is applied to the sites. Testing result shows that when sleep mode was activated, energy consumption decreased around $1.185 \%$ each day. Figure 8 shows comparison of daily energy consumption in one month when the sleep mode off and the sleep mode on.

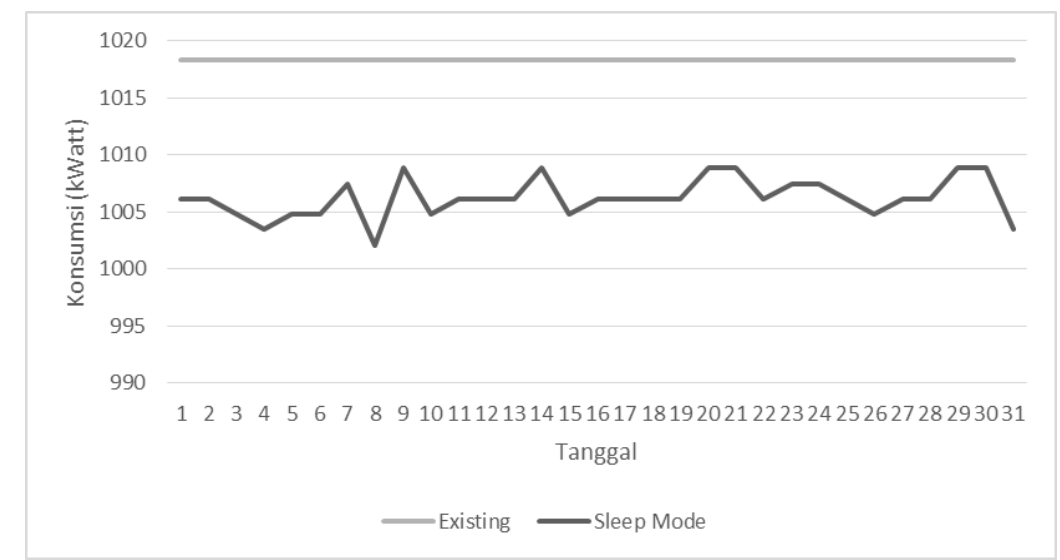

\section{Figure 8. Daily Energy Consumption when the Sleep Mode is Off and the Sleep Mode is on (1 Month)}

Comparison of energy consumption when the sleep mode is off and the sleep mode is on, is shown in Figure 9. In addition Figure 10 presents a comparison of annual energy consumption estimation when the sleep mode strategy is applied. The energy consumption on April was lower than March with and without sleep mode activated. Energy consumption is estimated around $1000 \mathrm{~kW}$ per day. When the sleep mode is implemented, energy consumption will decrease, for example on March it decreased up to 
$374 \mathrm{~kW}$ and on April decreased up to $200 \mathrm{~kW}$. As a result, when the sleep mode strategy is applied, it will reduce energy consumption up to $3,374 \mathrm{~kW}$ per annum.

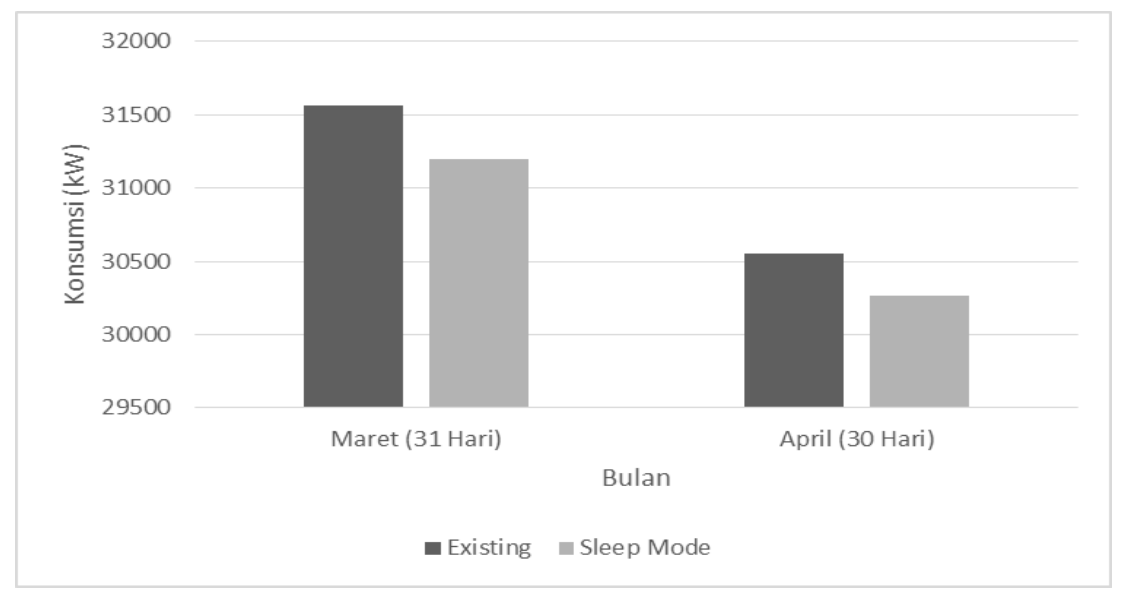

Figure 9. Monthly Energy Consumption with and without Sleep Mode Strategy (March - April)

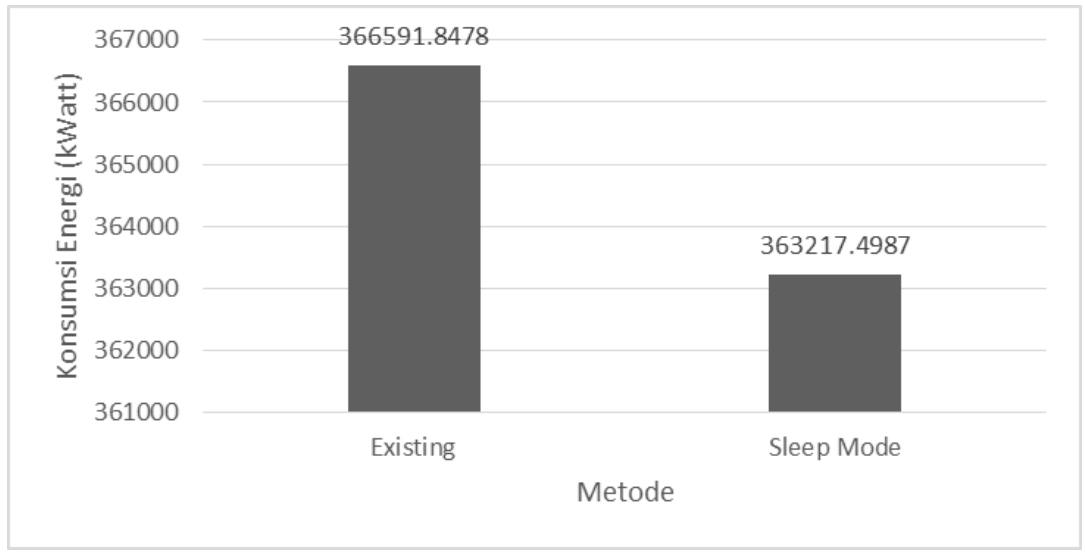

Figure 10. Estimated Annual Energy Consumption with and Without Sleep Mode Strategy

\subsection{Comparison of Energy Consumption Rating}

Figure 11 shows that the average ECR during sleep hours is higher than work hours without sleep mode strategy. This is due to low traffic load during sleep hours with high power consumption. The ECR on March was lower than in April. This shows that in March had better energy efficiency than in April. Similar with the implementation of the sleep mode strategy. During sleep mode, the ECR decreased up to 5,96 W/Gbps on March and 4,69 W/Gbps on April. 


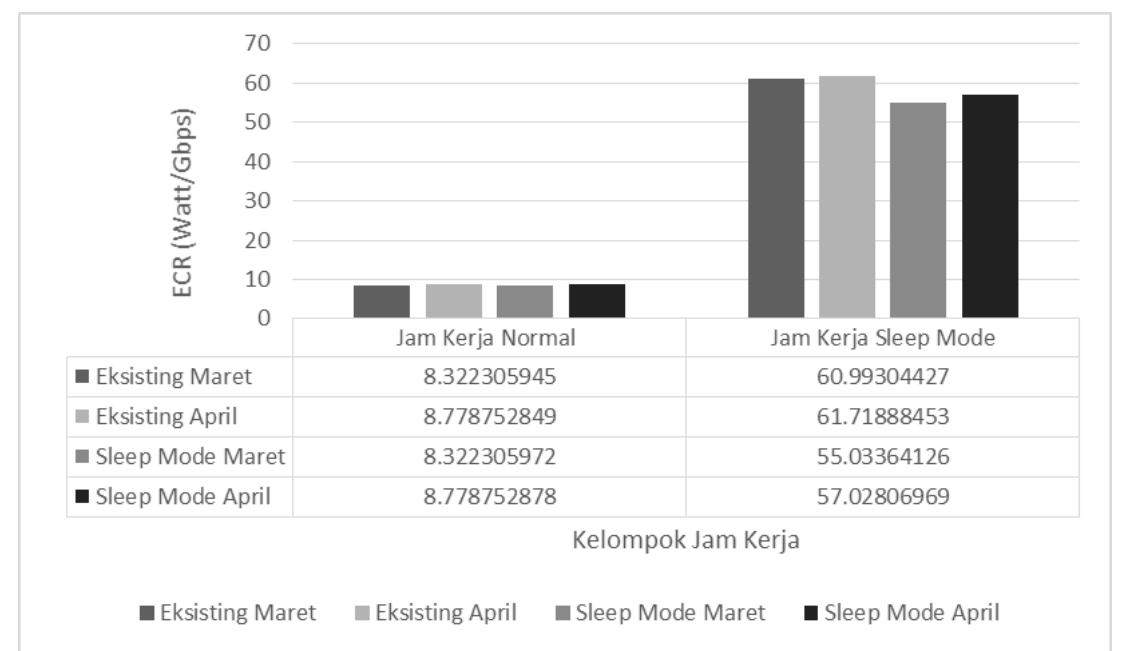

\section{Figure 11. Average ECR with and without Sleep Mode Strategy Implementation}

\subsection{Comparison of Area Power Consumption}

Figure 12 shows that average APC at work hours had almost the same value with and without sleep mode activated. In addition the APC was the same during work hours and sleep hours when the sleep mode inactive.

However when the sleep mode was activated, there were different value of APC between work hours and sleep hours. The APC value decreased during the sleep hours. The energy consumption per kilometer square could be reduced significantly. Thus the sleep mode strategy has proved its contribution in saving energy. The results found that the APC reduced about $146.487 \mathrm{~W} / \mathrm{km}^{2}$ on March and $111.98 \mathrm{~W} / \mathrm{km}^{2}$ on April.

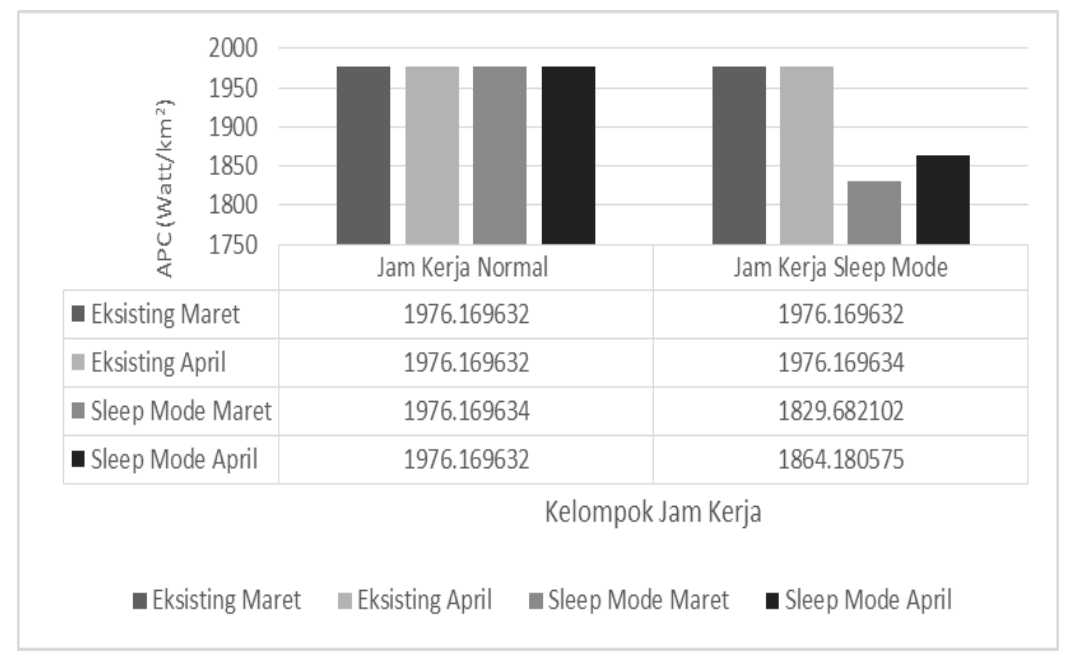

\section{Figure 12. Average APC with and without Sleep Mode Strategy Implementation}

\subsection{Comparison of Area Power Consumption per Data Rate $(\gamma)$}

The Area Power Consumption per Data Rate $(\gamma)$ on March at work hours was lower than on April, as shown in Figure 13. It was caused by the higher traffic on March. 
During sleep hours, the $\gamma$ was higher than normal hour because at sleep hours, the traffic was lower but the power consumption was still the same at in normal hours.

When sleep mode strategy implemented, the $(\gamma)$ on March was lower than April. In general, when sleep mode implemented during sleep hours, energy consumption was reduced. During the sleep hours, the $\gamma$ was reduced to $0.22 \mathrm{~W} / \mathrm{km}^{2} \mathrm{Gbps}$ on March and $0.17 \mathrm{~W} / \mathrm{km}^{2} \mathrm{Gbps}$ on April.

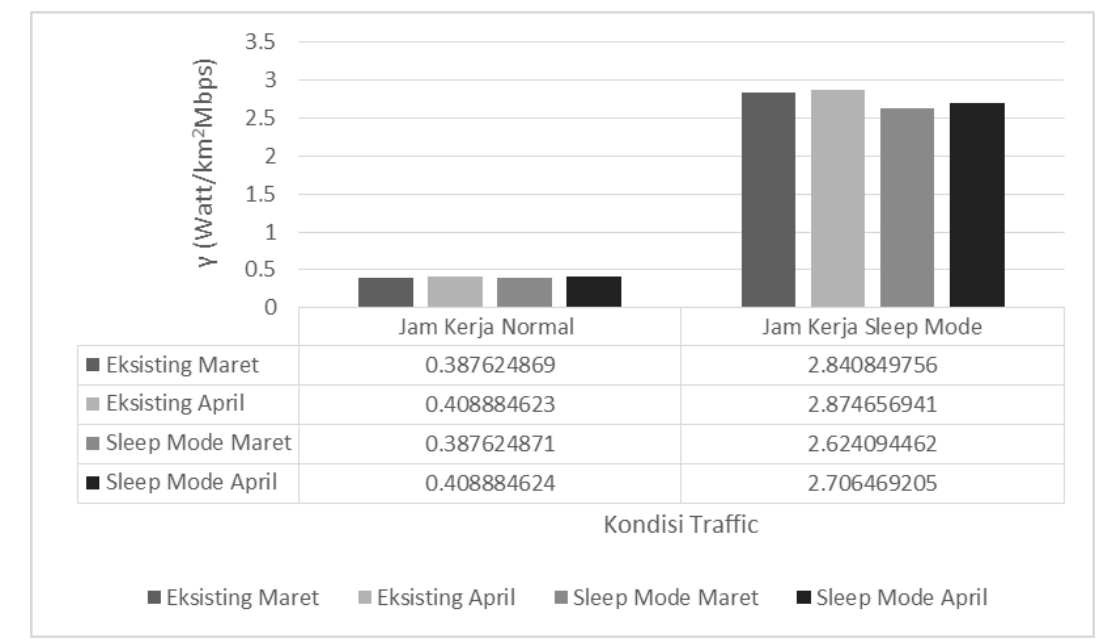

\section{Figure 13. Average of $(\Gamma)$ with and Without Sleep Mode Strategy Implementation}

\section{Conclusion}

In conclusion, sleep mode strategy has demonstrated significant contribution in energy saving in cellular network. The experiments and field testing has done in one District of a City and for Base Stations of one Provider. Therefore the sleep mode strategy is promising large energy saving when it is implemented in the city.

The implementation of the strategy in a District and the network from single Provider has found that the reduction of energy consumption was up to $10 \mathrm{~kW}$ per day. Then, it will be up to 3,374 $\mathrm{kW}$ a year. Moreover the implementation of strategy for energy saving was measured and verified using the ECR, APC, and the Area Power Consumption per Data Rate $(\gamma)$.

On the other hand, when the sleep mode was activated, there was a reduction about $3.10 \%$ of $3 \mathrm{G}$ services and the BTS coverage area. However this reduction services could be covered and substituted by $2 \mathrm{G}$ services of the provider.

\section{References}

[1] CISCO, "Cisco Visual Networking index: Global Mobile Data Traffic Forecast Update 2010 - 2015", (2010).

[2] D. Mahardy, "Dijegal Indosat, XL kembali terjungkal ke posisi tiga", http://www.techno.id/telco/dijegal-indosat-xl-kembali-terjungkal-ke-posisi-tiga-150618u.html, accessed on June 18, 2015.

[3] Population Projection, "Population of Denpasar Municipality by Age Group 2010 - 2015", http://denpasarkota.bps.go.id/linkTabelStatis/view/id/19, accessed on May 1, 2016.

[4] E. P. Setyanti, "4G LTE Tahap Dua Disahkan, Bagaimana Perbandingan Kecepatan dari 5 Operator Telekomunikasi di Indonesia”, https://id.techinasia.com/perbandingan-kecepatan-4g-indonesiatelkomsel-indosat-xl-tri-smartfren, accessed on May 1, 2016.

[5] M. Simone, P. Pierpaolo and E. D. Re, "Improving Cellular Network by Joint Management of Sleep Mode and Transmission Power", IEEE, Digital Communications - Green ICT (TIWDC), 2013 24th Tyrrhenian International Workshop on, (2013). 
[6] P. Yu. W. Li and X. Qiu, "Self-Organizing Energy-Saving Management Mechanism Based on Pilot Power Adjustment in cellular Network", International Journal of Distributed Sensor Networks, vol. 2012, (2012), pp. 1-13.

[7] O. Eunsung, K. Bhaskar, L. Xin and N. Zhisheng, "Toward Dynamic Energy-Efficient Operation of Cellular Network Infrastructure”, IEEE Communication Magazine, vol. 49, no. 6, (2011), pp. 56-61.

[8] W. Xiaofei, V. V. Athanasios, C. Min, L. Yunhao and K.T. Taekyoung, "A Survey of Green Mobile Networks: Opportunity and Challenges", Springer, Mobile Networks and Applications, February 2012, vol. 17, no. 1, (2012), pp. 4-20.

[9] A. Gunther, G. Vito, G. Istvan, S. Per, O. Magnus, I. M. Ali, S. Dario, J. G. Manuel, D. Claude and B. Oliver, "Cellular Energy Efficiency Evaluation Framework", European Community's 7th Framework Programme FP7/2007-2013, Project EARTH, (2013).

[10] M. R. Karim and M. Sarraf, "W-CDMA and Cdma2000 for 3G Mobile Networks", New York: McGraw-Hill, (2002).

\section{Authors}

Linawati, graduated and got $\mathrm{PhD}$ degree from Department of Electrical and Telecommunications, University of New South Wales in Year 2004. Her research interests are on network performance, load and traffic estimation, green network, and QoS analysis. Since year 1991 - present, Department of Electrical and Computer Engineering, Udayana University, Bali, Indonesia.

Gede Sukadarmika, currently teaching at Department of Electrical and Computer Engineering, Udayana University, Bali, Indonesia. His research interests are on elearning, green telecommunication, and green computing.

Ridho Yurham, he received his Bachelor Degree in Year 2014. His research interests are on telecommunication network and QoS analysis. 
International Journal of Multimedia and Ubiquitous Engineering

Vol.12, No.2 (2017) 